Bul. Agrohorti 3 (1): 18-27 (2015)

\title{
Pengamatan Uji Daya Berkecambah dan Optimalisasi Substrat \\ Perkecambahan Benih Kecipir [Psophocarpus tetragonolobus L. (DC)]
}

\section{Evaluation of Seeds Germination Test and Optimalization Substrates Germination of Winged Bean Seed [Psophocarpus tetragonolobus $L .(D C)$ ]}

\author{
Anggit Dwi Rahayu dan Tatiek Kartika Suharsi* \\ Departemen Agronomi dan Hortikultura, Fakultas Pertanian, Institut Pertanian \\ Bogor Jalan Meranti, Kampus IPB Dramaga, Bogor 16680, Indonesia \\ Telp. \& Faks.62-251-8629353 e-mail: agronipb@indo.net.id \\ *Penulis korespondensi: t.suharsi@yahoo.co.id.
}

Disetujui 7 Januari 2015/ Publish online 15 januari 2015

\begin{abstract}
Avaiability and utilization of indigenous vegetable is still limited. Seed testing become an importance fundamental to fulfill consumption and production of indigenous vegetable. The objectives of this research were to evaluate: (1) the development of winged bean's germination methods in first count and final count aspect; (2) selected an alternative substrates for germination. This research was conducted at IPB Seed Storage and Seed Quality Testing Laboratory for five months. This research consisted of two experiments, the first experiment is to determine first and final count, the second is optimalization of substrates germination. Results of this research showed that count determination in germination test of winged bean seed used eco-germinator type, performed in days $6^{\text {th }}$ for the first count and days $8^{\text {th }}$ for the final count. CD paper should be used as an alternative substrates if the seed testing used UKDdp methods. Sand substrates control with in sand methods is the best substrate if the seed testing applicated without paper substrates.
\end{abstract}

Keywords: CD paper, first count, final count, sand, winged bean seed

\begin{abstract}
ABSTRAK
Ketersediaan dan pemanfaatan dari sayuran indigenous masih sangat terbatas. Pengujian mutu benih menjadi langkah dasar yang penting untuk memenuhi kebutuhan produksi dan konsumsi dari sayuran indigenous. Penelitian ini bertujuan: (1) pengembangan metode uji daya berkecambah benih kecipir pada aspek penentuan pengamatan hitungan pertama dan kedua; (2) pemilihan substrat alternatif perkecambahan. Penelitian dilaksanakan di Laboratorium Pengujian Mutu Benih dan Penyimpanan Benih IPB selama lima bulan. Penelitian dibagi ke dalam dua percobaan, percobaan pertama yaitu penentuan hitungan pertama dan kedua, percobaan kedua yaitu optimalisasi substrat perkecambahan. Hasil penelitian menunjukkan bahwa penentuan hitungan dalam pengamatan uji daya berkecambah benih kecipir menggunakan alat pengecambah tipe eco-germinator dilakukan pada hari ke-6 untuk hitungan pertama dan hari ke-8 untuk hitungan kedua. Kertas CD dapat digunakan sebagai substrat kertas alternatif apabila pengujian benih menggunakan metode UKDdp. Substrat pasir kontrol dengan metode in sand merupakan substrat terbaik apabila pengujian benih dilakukan tanpa menggunakan substrat kertas.
\end{abstract}

Kata kunci: hitungan pertama, hiutngan kedua, kertas CD, pasir, benih kecipir 


\section{PENDAHULUAN}

Sayuran indigenous adalah sayuran lokal/daerah yang diusahakan oleh masyarakat atau sayuran yang berasal dari introduksi dan sudah dikenal oleh masyarakat (Diperta, 2012). Saat ini, pemanfaatan sayuran indigenous belum dikenal secara luas oleh masyarakat dan ketersediaannnya di pasaran masih terbatas. Kecipir (Psophocarpus tetragonolobus (L.) DC) merupakan salah satu jenis sayuran indigenous yang dibudidayakan di Indonesia. Kecipir merupakan tanaman legum potensial yang dapat dibudidayakan di daerah tropis dengan kandungan protein dan minyak yang tinggi pada bijinya (Mohanty, 2013). Kecipir merupakan tanaman multifungsi karena hampir seluruh bagian tanaman dapat dimanfaatkan mulai dari polong muda, umbi, daun muda, bunga dan bijinya. Komposisi nutrisi yang terdapat pada polong mudanya setara dengan tanaman kacangkacangan lainnya (Krisnawati, 2010).

Produksi kedelai terus mengalami penurunan sejak tahun 2009 hingga tahun 2012. Penurunan ini mengakibatkan defisit dengan ratarata sebesar $20.38 \%$ per tahun. Produksi dalam negeri hanya mampu menyediakan 29\% dari konsumsi total (Bappenas, 2013). Biji kecipir diharapkan dapat menjadi solusi alternatif kesenjangan yang terjadi antara produksi nasional dan konsumsi nasional kedelai. Biji kecipir telah banyak diteliti untuk dimanfaatkan sebagai olahan pangan yang menggunakan kedelai sebagai bahan bakunya namun, budidaya tanaman kecipir masih sangat terbatas pada beberapa lokasi. Menurut Copeland dan Donald (2001) pemahaman akan proses perkecambahan menjadi dasar yang penting terkait pemenuhan dan keseimbangan antara kebutuhan produksi untuk konsumsi dan jumlah populasi untuk mencapai produksi yang maksimum.

Pengujian mutu benih merupakan hal rutin yang dilakukan dalam rangka proses sertifikasi. Salah satu pengujian rutin yang dilakukan adalah pengujian daya berkecambah. Pengujian daya berkecambah memerlukan kondisi optimum pada media perkecambahan, suhu dan kelembaban. Berdasarkan penelitian Susanti (2010) terdapat perbedaan kecenderungan dari setiap jenis benih tanaman tentang media yang sesuai untuk perkecambahannya. Berdasarkan rekomendasi ISTA (2014a), media yang digunakan untuk perkecambahan benih adalah media kertas (kertas saring, kertas blotter, dan kertas towel), pasir dan media organik. Beberapa media terutama media kertas yang direkomendasikan ISTA menemui beberapa kendala dalam penggunaannya di
Indonesia, di antaranya harga yang cukup mahal dan ketersediaan yang terbatas. Hal lain yang penting diperhatikan dalam pengujian daya berkecambah adalah lamanya waktu pengujian. Penelitian Anasthasia (2014) menunjukkan bahwa terdapat perbedaan kondisi untuk perkecambahan benih di Indonesia khususnya pada alat pengecambah benih IPB 72-1. APB IPB 72-1 bersifat eco germinator yang artinya proses perkecambahan dalam alat tersebut dipengaruhi oleh faktor lingkungan seperti RH dan suhu yang cenderung fluktuatif. Hal ini mengakibatkan perbedaan lamanya pengujian berdasarkan rekomendasi ISTA dengan pengujian di Indonesia.

Oleh karena itu, penelitian mengenai penentuan pengamatan daya berkecambah dan optimalisasi substrat perkecambahan penting untuk dilakukan agar dapat mengetahui kondisi pengujian yang tepat untuk mengetahui keragaan benih yang akan ditanam di lapangan sehingga dapat dihasilkan produksi yang maksimal untuk pemenuhan kebutuhan konsumsi. Tujuan penelitian ini yaitu pengembangan metode uji daya berkecambah benih kecipir pada aspek penentuan pengamatan hitungan pertama dan kedua serta pemilihan substrat alternatif untuk perkecambahan.

\section{BAHAN DAN METODE}

Penelitian dilaksanakan di Laboratorium Pengujian Mutu Benih dan Penyimpanan Benih, Departemen Agronomi dan Hortikultura, Fakultas Pertanian, Institut Pertanian Bogor pada bulan Januari sampai dengan Mei 2015. Bahan yang digunakan dalam penelitian ini adalah benih kecipir yang diperoleh dari petani di Kabupaten Cilacap, Provinsi Jawa Tengah, kertas saring, kertas merang, kertas $\mathrm{CD}$, pasir, arang sekam sebagai substrat perkecambahan, natrium hipoklorit, label, amplop kertas, amplas kasar, selotip, plastik PE dan akuades. Alat-alat yang digunakan antara lain spiral separator, alat pengecambah benih tipe IPB 72-1, alat pengepres kertas tipe IPB 75-1, autoclave, oven, gunting stek, saringan pasir, stoples kaca, glass jar, wadah plastik, termohigrometer, bak plastik, gunting, handsprayer, dan alat tulis. Penelitian dibagi ke dalam dua percobaan. Percobaan 1 yaitu pengamatan penentuan uji daya berkecambah menggunakan substrat perkecambahan kertas saring. Setiap perlakuan terdiri atas 4 ulangan yang masing-masing terdiri atas 100 butir benih. Percobaan 2 yaitu optimalisasi substrat perkecambahan, menggunakan rancangan acak lengkap (RAL) faktor tunggal dengan 4 substrat 
perkecambahan uji dan 2 substrat sebagai kontrol. Setiap perlakuan terdiri atas 4 ulangan sehingga menghasilkan 24 satuan percobaan.

\section{Persiapan pendahuluan}

Pelaksanaan percobaan diawali dengan sortasi benih kecipir menggunakan spiral separator agar ukuran benih seragam. Benih yang telah disortasi kemudian diukur kadar airnya menggunakan metode oven suhu rendah. Selanjutnya untuk benih yang akan dikecambahkan dilakukan sterilisasi permukaan benih dengan merendam benih menggunakan natrium hipoklorit $1 \%$ selama 5 menit. Setelah itu benih dikeringanginkan kemudian dilakukan skarifikasi benih menggunakan amplas kasar. Skarifikasi dilakukan dengan cara menggosok bagian punggung dan pinggir benih. Benih yang telah diskarifikasi direndam kembali dalam natrium hipoklorit selama 10 detik.

\section{Percobaan 1. Penentuan hari pengamatan dalam} uji daya berkecambah

Percobaan 1 dilakukan dengan mengecambahkan 400 butir benih kecipir pada media kertas saring. Pengecambahan menggunakan kertas saring dilakukan dengan metode uji kertas digulung didirikan dilapisi plastik (UKDdP). Benih ditanam pada kertas saring yang telah dilembabkan menggunakan akuades. Benih yang ditanam sebanyak 25 butir pada setiap gulung. Setelah itu benih dikecambahkan pada alat pengecambah benih tipe IPB 72-1.

\section{Percobaan 2. Optimalisasi substrat perkecambahan benih kecipir}

Benih dikecambahkan pada empat macam substrat perkecambahan, yaitu substrat kertas merang, substrat kertas CD, substrat pasir (metode penanaman top of sand), dan substrat arang sekam dan 2 substrat sebagai kontrol, yaitu substrat kertas saring dan substrat pasir (metode penanaman in sand). Pada perlakuan yang menggunakan substrat pasir atau arang sekam, dilakukan perlakuan pendahuluan berupa penyaringan substrat. Substrat pasir disaring menggunakan saringan dengan ukuran $1 \mathrm{~mm}$ dan arang sekam dengan ukuran $2 \mathrm{~mm}$. Selanjutnya dilakukan sterilisasi substrat menggunakan autoclave pada suhu $121^{0} \mathrm{C}$ pada tekanan 17.5 psi selama 60 menit. Baik pasir maupun arang sekam yang telah steril dimasukkan ke dalam wadah plastik perkecambahan.
Benih yang dikecambahkan sebanyak 25 butir untuk setiap ulangan. Untuk substrat pasir perlakuan kontrol, benih ditanam dengan metode in sand, yaitu menanam benih dengan cara ditekan ke dalam pasir kemudian bagian atas benih dilapisi kembali dengan pasir lapisan tipis. Pengecambahan untuk perlakuan substrat pasir (non kontrol) dilakukan dengan metode top of sand, yaitu menanam benih hanya dengan menekan di permukaan media saja. Benih yang telah dikecambahkan dalam wadah plastik diletakkan pada rak dalam laboratorium benih untuk diamati proses perkecambahannya.

Perlakuan pengecambahan benih pada substrat kertas saring, kertas merang, dan kertas CD dilakukan dengan metode uji kertas digulung didirikan dilapisi plastik (UKDdp). Kertas dilembabkan menggunakan aquades kemudian ditiriskan. Bagian bawah kertas dilapisi plastik kemudian diletakkan 3 lembar kertas lembab. Benih dikecambahkan sebanyak 25 butir untuk setiap ulangan. Bagian atas ditutup kembali dengan 3 kertas lembab kemudian digulung dan diberi label. Selanjutnya seluruh perlakuan substrat kertas dikecambahkan dalam alat pengecambah benih tipe IPB 72-1.

Pengamatan yang dilakukan pada percobaan 1 yaitu mengamati jumlah kecambah normal yang tumbuh. Pengamatan dilakukan setiap hari selama 14 hari. Kriteria kecambah normal yang digunakan adalah memiliki akar primer dan sekunder, hipokotil, kotiledon, epikotil dan plumula (ISTA 2014b) dengan panjang kecambah dua kali panjang benih. Pengamatan pada percobaan 2 dilakukan terhadap tiga peubah yaitu viabilitas total dengan tolok ukur potensi tumbuh maksimum (PTM), viabilitas potensial dengan tolok ukur daya berkecambah (DB) dan berat kering kecambah normal (BKKN) serta vigor benih dengan indeks vigor (IV), keserempakan tumbuh (Ksт) dan kecepatan tumbuh $\left(\mathrm{K}_{\mathrm{CT}}\right)$.

Data yang telah didapatkan pada percobaan 1 dianalisis menggunakan analisis grafik dengan software Microsoft Excel 2013 untuk memperoleh puncak grafik sebagai hari hitungan pertama dan kedua. Software lainnya yang digunakan untuk menentukan hari hitungan adalah Minitab 16. Data yang diperoleh pada percobaan 2 dianalisis menggunakan uji $\mathrm{F}$, karena hasil berpengaruh nyata maka dilanjutkan dengan uji lanjut $t$ Dunnett pada taraf 5\%. Analisis data menggunakan software SAS 9.1. 


\section{HASIL DAN PEMBAHASAN}

\section{Kondisi Umum Benih dan Viabilitas Awal Benih Kecipir}

Benih kecipir yang digunakan merupakan benih lokal Cilacap yang berasal dari petani produksi di Kabupaten Cilacap, Provinsi Jawa Tengah. Benih yang digunakan berwarna coklat muda dengan bentuk bulat. Bagian tengah benih terdapat lingkaran oval berwarna coklat muda dengan bagian tengah berwarna lebih gelap adalah hilum dari benih. Bagian ujung hilum terdapat titik kecil hitam yang menunjukkan mikrofil benih. Benih yang digunakan merupakan benih hasil panen pada bulan Oktober tahun 2014. Benih dipanen dalam bentuk polong kering kemudian dikupas dan disortasi dari kotoran secara manual. Sortasi bentuk dilakukan menggunakan alat spiral separator. Benih yang telah disortasi disimpan dalam ruang penyimpanan benih.

Pengukuran kadar air benih dilakukan sebelum penyimpanan. Kondisi awal benih kecipir memiliki kadar air rata-rata sebesar $11.7 \%$ setelah mengalami proses pengeringan menggunakan sinar matahari selama satu hari. Kondisi ini tergolong kondisi kadar air yang aman untuk penyimpanan benih kecipir yang termasuk ke dalam kelompok benih ortodoks. Berdasarkan penelitian Indartono (2011) pada benih kedelai yang tergolong benih ortodoks, benih yang memiliki kadar air diatas $13 \%$ akan mengalami kemunduran lebih cepat. Benih memerlukan kadar air optimum untuk penyimpanannya. Sebagian besar benih memiliki kadar air optimum penyimpanan 6-11\%. Purba et al. (2013) menyatakan bahwa kemunduran benih selama masa penyimpanan disebabkan oleh kadar air benih yang semakin tinggi. Hal ini mengakibatkan laju respirasi semakin cepat sehingga semakin banyak $\mathrm{CO} 2$ dan panas yang dihasilkan. Aktivitas fisiologis ini dapat ditekan melalui kadar air penyimpanan yang ideal sehingga daya berkecambah benih masih dapat dipertahankan hingga waktunya benih dikecambahkan.

Ruang penyimpanan benih yang digunakan merupakan ruangan dengan suhu dan kelembaban terkontrol. Suhu ruang simpan berkisar antara 18$19^{\circ} \mathrm{C}$ dengan kelembaban berkisar antara 35$39 \%$. Penyimpanan benih bertujuan untuk mempertahankan viabilitas benih agar tetap tinggi sampai benih tersebut ditanam. Wadah yang digunakan untuk penyimpanan benih adalah toples kaca. Toples kaca dipilih sebagai wadah penyimpanan benih karena kedap udara sehingga dapat mempertahankan kadar air benih selama masa penyimpanan. Benih disimpan sejak bulan Oktober 2014 sampai dengan bulan Desember 2014. Alat pengecambah benih tipe IPB 72-1 yang digunakan untuk mengecambahkan memiliki kisaran suhu $27-28.5^{\circ} \mathrm{C}$ dengan kelembaban relatif sebesar $92 \%$ dan kondisi ruangan laboratorium memiliki suhu rata-rata sebesar $27.8^{\circ} \mathrm{C}$ dengan kelembaban relatif lebih rendah yaitu $70.8 \%$.

Daya berkecambah benih kecipir pada pengujian awal sebesar $62 \%$. Hal ini dikategorikan daya berkecambah benih yang rendah. Standar daya berkecambah yang tergolong tinggi untuk hampir seluruh benih adalah $\geq 80 \%$. Daya berkecambah benih yang rendah disebabkan oleh proses imbibisi yang tidak serempak pada benih sehingga pertumbuhan benih menjadi kecambah normal tidak serempak dan banyaknya serangan cendawan saat benih dikecambahkan. Timbulnya banyak cendawan kemungkinan diakibatkan oleh mikroorganisme terbawa benih karena substrat perkecambahan, alat pengecambah benih, dan air yang digunakan sudah dikondisikan dalam kondisi steril. Ghangaokar dan Kshirsagar (2013) mengemukakan bahwa mikroorganisme yang merupakan seedborne disease paling banyak ditemukan pada benih yang tidak mendapatkan perlakuan benih. Adanya infestasi mikroorganisme ini membuat vigor dan daya berkecambah benih menjadi rendah.

\section{Penentuan Hari Pengamatan dalam Uji Daya Berkecambah}

Pengamatan pertama atau hitungan pertama untuk benih kecipir dilakukan pada hari ke-4 dan pengamatan kedua atau hitungan kedua dilakukan pada hari ke-14 (ISTA 2014c). Pengujian dalam penelitian ini dilakukan pada media kertas saring (filter paper) menggunakan benih sebanyak 100 butir dan dikecambahkan dalam alat pengecambah benih (APB) IPB tipe 72-1. Pengujian menunjukkan hasil bahwa pada hari ke4 belum ada kecambah normal yang muncul pada setiap ulangan.

Pengamatan hari ke-4 memperlihatkan struktur kecambah yang muncul hanya radikula. Pada hari ke-14 semua struktur kecambah normal mulai dari radikula, epikotil, hipokotil dan plumula sudah muncul. Namun, ukuran dari semua struktur kecambah normal sudah terlampau tinggi. Terdapat hipokotil yang sudah mengeluarkan cabang dan beberapa sudah mulai layu. Ukuran kecambah normal yang terlampau tinggi dan 
hampir menyerupai ukuran bibit menunjukkan adanya ketidaksesuaian hari pengamatan yang direkomendasikan oleh ISTA pada media dan suhu perkecambahan yang sama. Oleh karena itu dilakukan pengujian dengan hitungan pertama dan kedua berbeda dengan ketentuan ISTA untuk penentuan hari pengamatan dalam uji daya berkecambah.

Penentuan hari pengamatan dalam uji daya berkecambah benih kecipir dilakukan menggunakan 400 butir benih dengan media kertas saring (filter paper). Benih dikecambahkan dalam eco germinator yaitu APB IPB tipe 72-1. Setelah 14 hari dikecambahkan, kecambah normal baru muncul pada hari ke-7 tetapi jumlahnya masih sangat sedikit. Kecambah normal terbanyak terdapat pada hari ke-8. Pada hari ke-9 dan hari ke-10 masih cukup banyak muncul kecambah normal namun jumlahnya lebih sedikit dari hari ke-8. Jumlah kecambah normal mulai menurun pada hari ke-11 hingga hari ke-14 (Gambar 1).

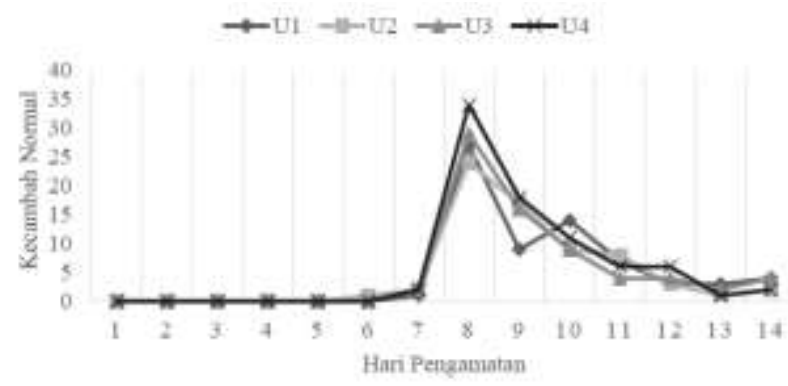

Gambar 1. Jumlah kecambah normal harian antar ulangan selama 14 hari pengamatan

Daya berkecambah benih yang diuji masih dikategorikan rendah yaitu $71.25 \%$ (Tabel 1). Hal ini disebabkan oleh banyaknya kecambah abnormal dan benih keras. Kecambah abnormal yang terdapat pada setiap ulangan masih berpotensi untuk menjadi kecambah normal, namun keterlambatan imbibisi mengakibatkan lambatnya pertumbuhan kecambah sehingga di akhir pengamatan masih belum dapat dikategorikan sebagai kecambah normal.

Tabel 1. Daya berkecambah benih kecipir tanpa skarifikasi

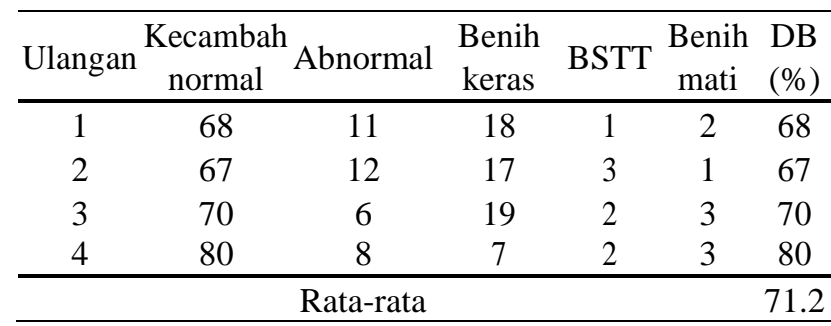

Keterangan: BSTT $=$ Benih Segar Tidak Tumbuh
Benih keras yang jumlahnya cukup tinggi diakibatkan oleh permasalahan pada proses imbibisi. Benih kecipir memiliki kulit yang cukup keras sehingga proses imbibisi pada sebagian benih terhambat. Hambatan yang terjadi pada benih kecipir ini disebut dengan dormansi fisik. Menurut Venier (2012), dormansi fisik atau yang dikenal dengan sifat impermeabel kulit benih terhadap air berkaitan dengan penampilan jaringan dari kulit benih. Sejak masalah dormansi ini memberikan perbedaan waktu dan rentang terhadap proses perkecambahan, mekanisme dormansi ini menjadi penting secara ekologi. Pada tiga spesies tanaman akasia (Acacia aroma, Acacia caven, dan Acacia atramentaria) yang memiliki dormansi fisik, impermeabilitas kulit benih pada spesies ini utamanya karena terdapat karakteristik berupa epidermis berlignin. Metode pematahan dormansi fisik diperlukan agar dapat mempermudah proses imbibisi.

Pengujian penentuan hari pengamatan yang selanjutnya dilakukan dengan jumlah benih, media, dan alat pengecambah yang sama. Metode pematahan dormansi dilakukan pada pengujian ini yaitu dengan skarifikasi fisikmenggunakan amplas kasar. Talei et al. (2012) menyebutkan pematahan dormansi yang dilakukan pada benih sambiloto menggunakan kertas pasir (amplas) juga memberikan daya berkecambah tertinggi dan daya berkecambah tercepat jika dibandingkan dengan metode skarifikasi fisik dan kimia lainnya. Benih di amplas pada bagian punggung benih dan pinggir sehingga tidak mengenai bagian embrio. Benih diamplas menggunakan amplas kasar sebanyak tiga kali gosokan pada setiap bagiannya hingga terdapat sedikit luka dan warna kulitnya pudar. Proses imbibisi yang terjadi pada benih lebih serempak setelah dilakukan proses skarifikasi. Pada hari kedua setelah tanam semua benih telah mengalami proses imbibisi.

Kecambah normal muncul lebih cepat yaitu pada hari ke-5 namun jumlahnya masih sedikit pada setiap ulangan. Puncak kecambah normal terjadi pada hari ke-6 dan hari ke-7. Pada hari ke8 masih cukup banyak terdapat kecambah normal yang muncul namun jumlahnya tidak sebanyak hari ke-6 dan hari ke-7. Setelah hari ke-8 jumlah kecambah normal terus mengalami penurunan hingga hari ke-14 (Gambar 2). Daya berkecambah pada pengujian ini jauh lebih baik dibandingkan sebelum dilakukan skarifikasi yaitu menjadi $96.5 \%$. 


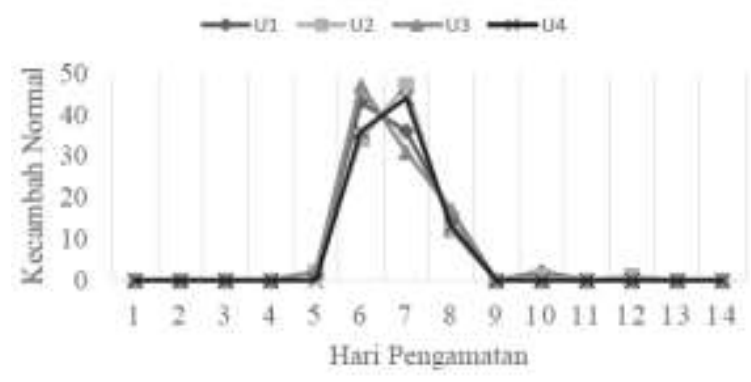

Gambar 2. Jumlah kecambah normal harian selama 14 hari pengamatan setelah skarifikasi

Berdasarkan hasil uji-t, dua puncak kecambah normal pada hari ke-6 dan hari ke-7 tidak berbeda nyata (Tabel 2) sehingga dapat diambil hari pengamatan pertama atau hitungan pertama adalah hari ke- 6 dan hari pengamatan kedua atau hitungan dua pada hari ke-8.

Tabel 2. Penentuan hitungan pertama pada benih kecipir

\begin{tabular}{cc}
\hline Hari pengamatan & Jumlah kecambah normal \\
\hline 6 & $40.0^{\mathrm{tn}}$ \\
7 & $39.5^{\mathrm{tn}}$
\end{tabular}

Keterangan: tn $=$ tidak nyata berdasarkan uji-t pada taraf 5\%

Terdapat hal menarik yang ditemukan dalam penelitian ini. Pada pengamatan kecambah normal harian, ditemukan beberapa kecambah poliembrioni. Pada umumnya struktur kecambah normal yang muncul adalah hanya satu kecambah normal dari satu benih yang terdiri atas akar primer dan sekunder, kotiledon, hipokotil, epikotil dan plumula. Dari satu benih yang sama muncul dua sampai tiga kecambah normal. Namun jumlah kecambah poliembrioni tidak banyak, hanya sekitar 6 kecambah poliembrioni dari 400 benih yang dikecambahkan.

\section{Optimalisasi Substrat Perkecambahan}

Hasil analisa sidik ragam pengaruh substrat perkecambahan terhadap semua peubah yang diamati disajikan pada Tabel 3. Faktor tunggal substrat perkecambahan berpengaruh sangat nyata terhadap hampir seluruh tolok ukur vigor dan viabilitas yang diamati yaitu daya berkecambah (DB), indeks vigor (IV), kecepatan tumbuh ( $\mathrm{K}_{\mathrm{CT}}$ ), keserempakan tumbuh (Ksт), dan berat kering kecambah normal (BKKN). Hanya pada tolok ukur potensi tumbuh maksimum (PTM) saja substrat berpengaruh nyata.
Tabel 3 menunjukkan bahwa substrat perkecambahan sangat memengaruhi mutu fisiologis benih yang diuji. Substrat perkecambahan merupakan faktor penting yang mendukung proses perkecambahan karena mensuplai air yang diperlukan selama proses perkecambahan berlangsung. Sadjad (2008) menyatakan bahwa media perkecambahan baik waktu maupun kondisi lingkungan perkecambahan harus optimal untuk memenuhi segala sesuatu yang diperlukan benih sehingga sesuai dan merepresentasikan pertumbuhan potensial dari benih pada kondisi lapang yang optimum.

Tabel 3 Rekapitulasi hasil sidik ragam pengaruh subsrat perkecambahan terhadap tolok ukur vigor dan viabilitas benih kecipir

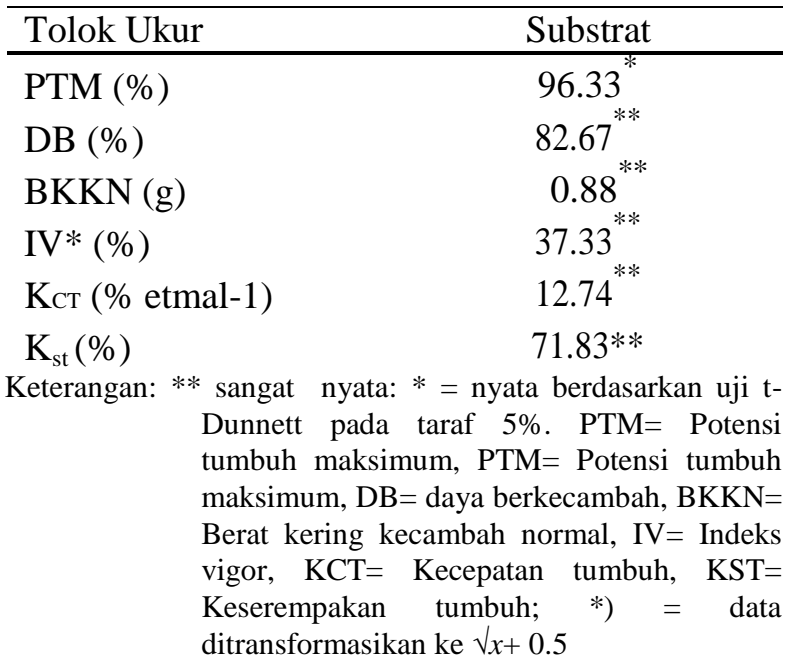

Hasil pembandingan subsrat uji dengan substrat kontrol menunjukkan hasil bahwa pada tolok ukur daya berkecambah, substrat arang sekam berbeda nyata lebih rendah dari substrat kertas saring. Berdasarkan nilai rataan benih yang dikecambahkan pada substrat arang sekam memiliki daya berkecambah terendah dibandingkan dengan empat substrat uji lainnya. Daya berkecambah terbaik dihasilkan oleh substrat kontrol pasir (in sand) yaitu 100\% (Tabel 4). Indeks vigor yang baik dihasilkan oleh substrat pasir (in sand), kertas $\mathrm{CD}$, dan kertas merang dibandingkan dengan kertas saring. Hasil uji tolok ukur kecepatan tumbuh menunjukkan bahwa substrat pasir (in sand) dan substrat kertas CD berbeda nyata lebih tinggi dengan substrat kertas saring dengan nilai rata-rata sebesar $18.7 \%$ dan $14.77 \%$ (Tabel 4). Substrat pasir (in sand), kertas merang, dan kertas CD berbeda nyata lebih tinggi dengan substrat kontrol kertas saring untuk keserempakan tumbuh.

Hasil pembandingan substrat uji terhadap substrat kontrol kertas saring menunjukkan bahwa 
substrat kertas CD berbeda nyata lebih tinggi pada tolok ukur IV, Kст, dan Ksт. Hal ini menunjukkan bahwa substrat kertas $\mathrm{CD}$ dapat digunakan sebagai substrat alternatif dalam pengujian benih kecipir apabila ingin menggunakan metode uji kertas digulung didirikan dalam plastik (UKDdp).

Tabel 4. Nilai rataan tolok ukur viabilitas dan vigor pada pembandingan substrat kontrol kertas saring (filter paper)

\begin{tabular}{|c|c|c|c|c|c|c|}
\hline \multirow{2}{*}{ Substrat } & \multicolumn{5}{|c|}{ Tolok ukur } & \multirow{2}{*}{ KST $(\%)$} \\
\hline & PTM (\%) & DB $(\%)$ & BKKN (g) & $\left.\mathrm{IV}^{*}\right)(\%)$ & KCT $\left(\%\right.$ etmal $\left.^{-1}\right)$ & \\
\hline Kertas saring & 97 & 90 & 0.96 & 8 & 11.36 & 57 \\
\hline Pasir (in sand) & $100^{\text {tn }}$ & $100^{\operatorname{tn}}$ & $0.95^{\text {tn }}$ & $98^{* *}$ & $18.70^{* *}$ & $100^{* *}$ \\
\hline Kertas merang & $100^{\operatorname{tn}}$ & $93^{\text {tn }}$ & $0.95^{\text {tn }}$ & $35^{* *}$ & $14.09^{\operatorname{tn}}$ & $86^{* *}$ \\
\hline Kertas CD & $97^{\mathrm{tn}}$ & $94^{\mathrm{tn}}$ & $1.06^{\mathrm{tn}}$ & $44^{* *}$ & $14.77^{* *}$ & $89^{* *}$ \\
\hline Arang sekam & $88^{\text {tn }}$ & $27^{* *}$ & $0.30^{* *}$ & ${ }_{6} \mathrm{tn}$ & $3.99^{* *}$ & $22^{* *}$ \\
\hline Pasir (TS) & $96^{\mathrm{tn}}$ & $92^{\text {tn }}$ & $1.09^{\text {tn }}$ & $33^{\text {tn }}$ & $13.50^{\mathrm{tn}}$ & $77^{\text {tn }}$ \\
\hline
\end{tabular}

Keterangan: $* *=$ berbeda nyata dengan perlakuan kertas saring berdasarkan hasil uji t Dunnett pada taraf 5\%; $\mathrm{tn}=$ tidak berbeda nyata dengan perlakuan kertas saring berdasarkan hasil uji t Dunnett pada taraf 5\%. PTM= Potensi tumbuh maksimum, $\mathrm{DB}=$ daya berkecambah, $\mathrm{BKKN}=$ Berat kering kecambah normal, $\mathrm{IV}=$ Indeks vigor, $\mathrm{KCT}=\mathrm{Kecepatan}$ tumbuh, KST= Keserempakan tumbuh, TS $=$ top of sand $;)=$ data ditransformasikan ke $\sqrt{ } x+0.5$

Selama proses perkecambahan berlangsung, kertas CD cukup mampu mempertahankan kelembaban. Hal ini sejalan dengan penelitian Suwarno dan Hapsari (2008) yang mengemukakan bahwa kertas CD memiliki kemampuan yang baik dalam kecepatan penyerapan air $(2.5 \mathrm{~cm} / 5$ menit $)$, mempertahankan air (jumlah air yang hilang selama 7 hari sebanyak $1.27 \mathrm{~g}$ air/unit media), dan menyerap air (28.14 g air/unit media). Kertas CD juga

merupakan substrat yang lebih baik jika dibandingkan dengan kertas merang. Jika dibandingkan dengan kertas saring, kertas merang hanya memberikan hasil indeks vigor dan keserempakan tumbuh yang lebih tinggi sedangkan kertas CD memberikan hasil indeks vigor, kecepatan tumbuh, dan keserempakan tumbuh yang lebih tinggi. Penelitian Suwarno dan Santana (2009) menunjukkan bahwa penggunaan kertas CD sebagai substrat perkecambahan benih besar menghasilkan tingkat kesamaan $100 \%$ jika dibandingkan dengan kertas kertas merang pada tolok ukur daya berkecambah dan memiliki tingkat kesamaan $80 \%$ pada peubah berat kering kecambah normal. Pembandingan dengan substrat pasir (in sand) menunjukkan bahwa kertas saring dan arang sekam memiliki nilai rataan terendah pada tolok ukur keserempakan tumbuh. Sama halnya dengan tolok ukur kecepatan tumbuh, tidak ada satu pun substrat uji yang menghasilkan indeks vigor yang lebih tinggi dari substrat pasir (in sand). Seluruh substrat uji berbeda nyata lebih rendah dengan perlakuan substrat kontrol pasir (in sand). Nilai indeks vigor yang dihasilkan pada perlakuan ini sebesar 98\% (Tabel 5). Nilai IV ini memperlihatkan bahwa benih kecipir yang dikecambahkan pada substrat pasir dengan metode in sand memiliki vigor yang sangat baik karena didukung lingkungan eksternalnya, dalam hal ini substrat, yang mampu mendukung proses perkecambahan dengan baik. Hal ini menunjukkan bahwa substrat pasir dengan metode in sand merupakan substrat terbaik untuk perkecambahan benih kecipir. Benih yang dikecambahkan dengan metode in sand dapat tumbuh lebih baik dibandingkan dengan metode top of sand karena kelembaban dalam substrat lebih terjaga. Benih mendapatkan kelembaban dari dua bagian, yaitu pasir lapisan bagian atas dan pasir lapisan bagian bawah. Pasir juga merupakan substrat yang porous sehingga mudah ditembus oleh akar kecambah. Murniati dan Suminar (2006a) mengemukakan bahwa setiap spesies benih memiliki media perkecambahan yang optimum dan spesifik untuk dapat mendukung proses perkecambahannya. Dalam penelitian ini, substrat pasir memiliki nilai yang cukup tinggi pada seluruh peubah pengamatan, namun hasil penelitian Yuniarti et al. (2000) menunjukkan bahwa benih tisuk yang dikecambahkan pada subsrat pasir memiliki daya berkecambah paling rendah jika dibandingkan dengan substrat vermikulit, sabut kelapa, tanah, dan campuran tanah + pasir. Arang sekam adalah perlakuan dengan hasil berat kering kecambah normal yang paling rendah jika dibandingkan dengan substrat pasir. Kecambah normal yang dihasilkan dari perlakuan substrat arang sekam berukuran lebih kurus terutama pada bagian radikula dan jumlahnya lebih sedikit. 
Bul. Agrohorti 3 (1): 18-27(2015)

Tabel 5. Nilai rataan tolok ukur viabilitas dan vigor pada pembandingan substrat kontrol pasir (in sand)

\begin{tabular}{|c|c|c|c|c|c|c|}
\hline \multirow{2}{*}{ Substrat } & \multicolumn{6}{|c|}{ Tolok ukur } \\
\hline & PTM $(\%)$ & $\mathrm{DB}(\%)$ & BKKN (g) & $\left.\mathrm{IV}^{*}\right)(\%)$ & $\mathrm{K}_{\mathrm{CT}}\left(\% \mathrm{etmal}^{-1}\right)$ & $\mathrm{K}_{\text {sт }}(\%)$ \\
\hline Kertas saring & $97^{\mathrm{tn}}$ & $90^{\mathrm{tn}}$ & $0.96^{\mathrm{tn}}$ & $8^{* *}$ & $11.36^{* *}$ & $57^{* * *}$ \\
\hline Pasir (in sand) & 100 & 100 & 0.95 & 98 & 18.70 & 100 \\
\hline Kertas merang & $100^{\operatorname{tn}}$ & $93^{\mathrm{tn}}$ & $0.95^{\mathrm{tn}}$ & $35^{* *}$ & $14.09^{* *}$ & $86^{\text {th }}$ \\
\hline Kertas CD & $97^{\text {tn }}$ & $94^{\mathrm{tn}}$ & $1.06^{\mathrm{tn}}$ & $44^{* *}$ & $14.77^{* *}$ & 89 tn \\
\hline Arang sekam & $88^{* *}$ & $27^{* * *}$ & $0.30^{* *}$ & $6^{* *}$ & $3.99^{* *}$ & $22^{* *}$ \\
\hline Pasir (TS) & $96^{\mathrm{tn}}$ & $92^{\text {tn }}$ & $1.09^{\mathrm{tn}}$ & $33^{* *}$ & $13.50^{* *}$ & $77^{\text {tn }}$ \\
\hline
\end{tabular}

Keterangan: $* *=$ berbeda nyata dengan perlakuan pasir (in sand) berdasarkan hasil uji t Dunnett pada taraf 5\%. PTM= Potensi tumbuh maksimum, $\mathrm{DB}=$ daya berkecambah, $\mathrm{BKKN}=$ Berat kering kecambah normal, IV= Indeks vigor, KCT= Kecepatan tumbuh, KST= Keserempakan tumbuh, TS= top of sand; $*$ ) $=$ data ditransformasikan ke $\sqrt{ } x+0.5$

Berdasarkan hasil uji terhadap seluruh substrat perkecambahan, tidak ada substrat yang berbeda nyata

dengan substrat kertas saring dan pasir (in sand) pada tolok ukur potensi tumbuh maksimum. Hanya arang sekam saja yang potensi tumbuh maksimumnya berbeda nyata lebih rendah dari substrat pasir (in sand). Hal ini disebabkan tolok ukur PTM hanya mengukur kemampuan benih untuk dapat tumbuh saja walaupun belum berkecambah normal, sehingga kurang menunjukkan perbedaan yang nyata dalam evaluasi hasil pengujian.

Substrat arang sekam memberikan hasil yang nyata lebih rendah dibandingkan substrat kertas saring pada tolok ukur DB, Kст, Kst dan BKKN. Keseluruhan hasil dari tolok ukur vigor dan viabilitas yang dibandingkan dengan substrat pasir (in sand) menunjukkan bahwa arang sekam memiliki nilai yang terendah. Sangat banyak benih abnormal yang terdapat pada pengujian menggunakan substrat arang sekam. Hal yang sama juga ditunjukkan pada penelitian Murniati dan Suminar (2006b) benih mengkudu yang dikecambahkan pada arang sekam memiliki nilai yang rendah pada tolok ukur PTM, DB, Kст relatif, dan vigor, walaupun perlakuan pra perkecambahan tidak responsif. Benih mengkudu mengalami dormansi karena faktor lingkungan yaitu media perkecambahannya. Namun pada penelitian ini benih kecipir yang ditanam di arang sekam sudah mengalami proses pematahan dormansi sehingga rendahnya daya berkecambah diduga bukan karena dormansi faktor lingkungan (enforced dormancy).

Selain itu, nilai PTM yang dihasilkan dari perlakuan substrat arang sekam cukup tinggi sehingga terhambatnya pertumbuhan menjadi kecambah normal diduga karena suplai air yang kurang untuk membuat benih tersebut menjadi kecambah normal.
Arang sekam mampu memegang air cukup baik, namun air yang ada lebih banyak lolos sehingga tidak dapat diserap oleh benih. Arang sekam lebih mudah kering jika dibandingkan dengan substrat lainnya. Hal tersebut kurang mendukung untuk perkecambahan benih yang baik karena air sangat diperlukan oleh benih yang sedang berkecambah untuk mengaktifkan enzim stimulan perkecambahan. Terlebih benih kecipir adalah benih besar sehingga memerlukan jumlah air yang lebih banyak dalam proses perkecambahannya. Penelitian Rahayu et al. (2008) pada tanaman seledri yang menggunakan media arang sekam juga menunjukkan hasil yang sama, bahwa hasil pertumbuhan paling rendah terdapat pada seledri yang ditanam pada media arang sekam. Hal ini disebabkan karena penguapan pada media ini sangat tinggi karena pori-porinya yang berukuran besar sehingga banyak unsur hara yang hilang.

\section{KESIMPULAN}

Penentuan hitungan dalam pengamatan uji daya berkecambah benih kecipir menggunakan alat pengecambah tipe eco-germinator dilakukan pada hari ke-6 untuk hitungan pertama dan hari ke-8 untuk hitungan kedua. Kertas CD dapat digunakan sebagai substrat kertas alternatif apabila pengujian menggunakan metode UKDdp. Substrat pasir kontrol dengan metode in sand merupakan substrat terbaik apabila pengujian dilakukan tanpa menggunakan substrat kertas. 


\section{DAFTAR PUSTAKA}

Anasthasia, S. 2014. Viabilitas dan daya simpan benih lobak (Raphanus sativus L.) lokal dan impor setelah disimpan pada ruang simpan berbeda [skripsi]. Bogor (ID): Institut Pertanian Bogor.

[Bappenas] Badan Pembangunan Nasional. 2013. Rencana jangka panjang dan menengah bidang pangan dan pertanian 2015-2019 [internet]. [diunduh 2014 Des 18]. Tersedia pada:www.bappenas.go.id

Copeland,L. O., Mc.Donald MB. 2001. Principles of Seed Science and Technology $4^{\text {th }}$ ed. London: Kluwer Academic Publishers.

[Diperta Jabar]. Dinas Pertanian Jawa Barat (ID). 2012. Mengenal sayuran indigenous

[ISTA] International Seed Testing Association. 2014a. International Rules for Seed Testing. Switzerland (CH): ISTA.

[ISTA] International Seed Testing Association. 2014c. International Rules for Seed Testing. Switzerland (CH): ISTA.

Krisnawati, A. 2010. Keragaman genetik dan potensi pengembangan kecipir (Psophocarpus tetranogolobus L.) di Indonesia. J.Litbang Pertanian 29(3): 113-119.

Mohanty, C.S., Verma, S., Singh, V., Khan, S., Gaur, P., Gupta, P., Nizar, M. A., Dikshit, N., Pattanayak, R., and Sukhla, A. et al. 2013. Characterization of winged bean (Psophocarpus tetranogolobus (L.) DC) based on molecular, chemical and physiological parameters. American Journal of Molecular Biology 3 (2013): 187-197. doi: 10.4236/ajmb2013.34025.

Murniati, E.,dan Suminar, M. 2006. Pengaruh jenis media perkecambahan dan perlakuan pra perkecambahan terhadap viabilitas benih mengkudu (Morinda citrifolia L.) dan hubungannya dengan sifat dormansi benih. Bul Agron. 34(2): 119-123.

Purba, H. W. S., Sitepu F. E., dan Haryati. 2013. Viabilitas benih rosella (Hibiscus sabdarifa [internet]. [diunduh 2014 Des 7]. Tersedia pada:http://diperta.jabarprov.go.id/index.php./ sub Menu/informasi/artikel/detailartikel/ 211.

Ghangaokar, N. M., Kshirsagar, A. D. 2013. Study of seed borne fungi of different legumes. Sci Journal [Internet]. [diunduh pada $2015 \mathrm{Mei}$ 22]; 2(1):32-35. Tersedia pada: http:// sciencejournal.in /data/documents/TLS-2-18.pdf.

Indartono. 2011. Pengkajian suhu ruang penyimpanan dan teknik pengemasan terhadap kualitas benih kedelai. Gema Teknologi 16(3): 158-163.

L.) pada berbagai kadar air awal dan kemasan benih. J Online Agrotek 1(2): 318-326.

Rahayu, M., Samanhudi, dan Widodo, A. S. 2008. Pengaruh macam media dan konsentrasi pupuk fermentasi ampas tahu terhadap pertumbuhan dan hasil tanaman seledri (Apium graveolens L.) secara hidroponik. $J$ Ilmiah Ilmu Tanah dan Agroklimatologi 5(2): 75-82.

Sadjad, S. 2008. The Phylosophy of Seed. Bogor (ID): IPB Pr.

Soetiarso, T. A. 2010. Sayuran indigenous alternatif sumber pangan benilai gizi tinggi. Iptek hortikutura (6):5-10. Tersedia pada: http://www.hortikultura.litbang.deptan.go.id.

Susanti, M. 2010. Pengaruh media tanam dan perlakuan pra perkecambahan terhadap perkecambahan benih panggal buaya (Zanthoxylum rhetsa (Roxb.) D.C.) [skripsi]. Bogor (ID): Institut Pertanian Bogor.

Suwarno, F. C, Hapsari I. 2008. Studi alternative substrat kertas untuk pengujian viabilitas benih dengan metode UKDdp. Bul Agron 36(2): 84-91. 
Suwarno, F.C., dan Santana, D. B. 2009. Efisiensi beberapa substrat dalam pengujian viabilitas benih berukuran besar dan kecil. JAI 37(3): 249-255.

Talei, D., Valdiani, A. Abdullah, M. P., and Hassan, S. A. 2012. A rapid and effective method for dormancy breakage and germination of King of Bitters (Andrographis paniculata Nees.) seeds. Maydica [Internet]. [diunduh 2015 Mei
21];57(2). Tersedia pada: http://crajournals.cineca.it/index.php./ maydica/article/view/696.

Venier, P., Funes, G., and Garcia, C.C. 2012. Physical dormancy and histological features of seeds of five Acacia species (Fabaceae) from xerophytic forests in central Argentina. J. Flora 207(1):39-46. doi: 10.1016/j.flora. 2011. 07.017.

Yuniarti, N. Heryati, Y. dan Rostiwati, T. 2000. Pemilihan metoda dan media uji perkecambahan benih tisuk (Hibiscus sp.). $J$ Agron 9(1): 43-47. 
Bul. Agrohorti 3 (1): 18-27 (2015) 